\title{
Law Reforming in the Anti-Poverty Effort
}

\author{
Geoffrey C. Hazard, Jr.†
}

The reforms in the law that could be made on behalf of the poor comprise a formidable agenda. The general aims of such reforms are to (1) facilitate lowering the cost of things the poor buy, (2) increase the income flow to the poor, either in money or in goods and services, and (3) modify the terms and procedures of exchange so that the poor are able to buy and sell on more advantageous terms. Most such reforms would intrude on established preserves and are politically controversial and technically intricate.

The problem of redistributing income or bargaining power in favor of disadvantaged groups is not new. It is the essence of making and remaking domestic policy. Conflict-often protracted and heated-is involved even where the merits of reform seem apparent, where the number of potential beneficiaries is large in relation to the interests opposing change, and where the stakes concern a necessary of life. Illustrative of such elemental conflicts are those concerning the fetters on selling margarine that had been imposed in favor of the dairy industry, ${ }^{1}$ and the current controversies over legal restrictions on the marketing of shoes, ${ }^{2}$ cotton clothing, ${ }^{3}$ and prescription drugs. ${ }^{4}$

Legal reforms aimed at such redistributions characteristically are achieved through the medium of legislation and by the mechanism

† Executive Director, American Bar Foundation, and Professor of Law, University of Chicago. This paper is one of several emanating from studies done under contract with the Office of Economic Opportunity, CAP 67-7075, Research Contract No. OEO-4047. The views stated are those of the author and do not necessarily represent those of the Office of Economic Opportunity or the American Bar Foundation, its officers and directors, or others associated with its work.

1 Porter, Oleomargarine-Pattern for State Trade Barriers, 29 S.W. Soc. Scr. Q. 38 (1948). Hearings on Oleomargarine Tax Repeal Before the House Comm. on Agriculture, 80th Cong., 2d Sess. (1948); 81st Cong., Ist Sess. (1949); Meissner, Consumer Protection or Butter Politics, 3 Cartel 49 (1952).

2 N.Y. Times, Dec. 8, 1969, at 17; N.Y. Times, July 13, 1969, at 15.

3 Textile Imports Are a National Problem, 118 TextrLe WorLd 72 (May 1968); Meeting Gavel Down on Imports, 118 TexTrLe WorLd 78 (Nov. 1968); 115 CoNG. REc. S7805 (daily ed. July 10, 1969) (remarks of Sen. Hollings).

4 Hearings on Competitive Problems in Drug Industry Before the Subcomm. on Monopoly of the Senate Select Comm. on Small Business, 90th Cong., 2d Sess. (1967-68) [parts 1-13 published to date]. 
of political action. The agents of change characteristically have been private individuals and groups, organized around common grievances and claims. Illustrations are abundant: the retail grocers and the Robinson-Patman Act, ${ }^{5}$ the unions and Medicare, ${ }^{6}$ farmers and parity, ${ }^{7}$ senior citizens and Social Security, ${ }^{8}$ the American Legion and veteran's pensions. ${ }^{9}$ Characteristically also, the private groups with direct interest in change seek alliance with others who have indirect, civic, or humanitarian purposes in mind. Hence, the political roles of such groups as the League of Women Voters, religious affiliations, and philanthropic organizations.

The legislative-political method of substantive legal reform is formally as accessible to the poor as it is to any other sector of the community. There are no special limits on the franchise to vote or the freedom to organize that apply to the poor but not to others. But the practical obstacles to law reform on behalf of the poor are formidable. For one thing, "the poor" are not a single constituency but many constituencies that are diverse in location, outlook, special need, and social associations. Moreover, these separate constituencies are generally speaking unorganized, to some extent politically unsophisticated, inadequately financed for political warfare, and not patient enough to persevere in the struggles that legislative reform entails. It is widely acknowledged that they have been less successful in securing substantive legal change in their interest than more affluent members of the community.

Awareness of the politically weak position of the poor has stimulated search for alternative courses of reform action. The most obvious legal alternative is the use of litigation, a medium which has been employed, with varying degrees of emphasis and success, by other groups that have wanted legal change. ${ }^{10}$ This mode of law reform has become a major component in the policy-and even more so in the

5 F. Rowe, Price Discrimlnation Under the Robinson-Patman Act 3 (1962).

6 Harris, Annals of Legislation: Medicare 42 NEw YoRkER 29 (July 2, 1966), 30 (July 9, 1966), 35 (July 16, 1966), 35 (July 23, 1966).

7 O. Kile, The farm Bureau Through Three Decades (1948); C. Campbell, The FARM BUREAU AND the NEW DEAL (1962).

8 R. Lubove, The Struggle for Social Security, 1900-1935 (1968); A. Altmeyer, The Formative Yrars of Soctal Security (1966).

a R. Jones, A History of American Legion (1946); R. Moley, The American Legion Story (1966); D. Culp, The Amerian legcion: A Study in Pressure Politics (1942) (unpublished Ph.D. dissertation, Univ. of Chicago).

10 E.g., Eastern Railroad Presidents Conf. v. Noerr Motor Freight, 365 U.S. 127 (1961); G. WOlfskill, The Revolt of the Conservatives; A History of the AMerican LiberTX LeAGUe, 1934-40 (1962); The Railroad-Trucker Brawl, 47 FortuNE 137 (June, 1953); Walden, More About Noer-Lobbying, Antitrust and the Right to Petition, 14 U.C.L.A.L. REv. 1211 (1967). 
rhetoric-of the Legal Services Program of the Office of Economic Opportunity.

Seeking to reform the law to benefit the poor is surely an appropriate concern of the Legal Services Program. As a practical matter, it is impossible to disassociate specific legal problems encountered by individuals who are poor from the social and legal matrix in which they arise. Directing legal service effort at change in the law's terms can result in greater "pay-off" than similar effort spent on isolated cases-effecting improvement, as it were, wholesale rather than retail. There is also a political and spiritual aspect to such a strategy: Trying to change the law is a sharing of discontent with the poor's condition of life as they find it and an expression of hope for the better.

What is not so clear, however, is whether the weight of the Legal Service Program's law reform effort is most usefully concentrated in the medium of litigation. The analysis presented here presents the question whether the law-reform potential of litigation through the Legal Services Program as presently conceived is not considerably exaggerated. ${ }^{11}$ The companion question is whether the potential role of the Legal Services Program in the more conventional mode of law reform-legislation-has been given adequate attention. ${ }^{12}$

\section{Law Reform Through the Judichary}

The strategy of seeking law reform through appellate litigation begins with the observation that courts in fact make and remake law. There was a time when this was not considered true. It is now generally recognized, however, that the decision of any seriously arguable legal controversy involves a creative intellectual act. American courts are so fully aware of the creative aspect of their function ${ }^{13}$ that judicial lawmaking is now something in the way of a continuously selffulfilling prophecy. When combined with the fact that American judges are recruited mostly from those who have had active political and governmental careers, where making policy is daily work, these circumstances produce a frankly reformist judicial attitude. So far as concerns reliance on the past as a guide to enunciation of law in the present, the courts today are scarcely distinguishable from the

11 See Cahn \& Cahn, The War on Poverty: A Civilian Perspective, 73 Yale L.J. 1317, 1340-4 (1964); Sparer, Social Welfare Law Testing, 12 PRAc. LAw 13 (1966).

12 See Pye, The Role of Legal Services in the Anti-Poverty Program, 31 Law \& CONTEMP. Prob. 211, 247-8 (1966).

13 See W. Schaefer, Precedent and Policy (1956); Breitel, The Courts and Lawmaking in Legal Institutions Todax AND TOMORRow I (M. Paulsen ed. 1959); Traynor, The WellTempered Judicial Decision, 21 ARK. L. Rev. 287 (1967). 
legislature. This is especially apparent in light of the fact that both legislatures and courts oscillate between reform and repose.

The courts have also evolved devices that to some degree approximate the legislature's capacity to time and to mold new law in such a way as to minimize disruption at the point of enforcement. A new judicial rule can be forecast, postponed as to its effective date, or announced in principle, subject to later elaboration of detail, ${ }^{14}$ fashioned narrowly or broadly; ${ }^{15}$ its wisdom and effect illuminated through such devices as intervention, ${ }^{16}$ presentations amicus curiae, ${ }^{17}$ reargument, ${ }^{18}$ and remand for supplemental evidence. ${ }^{19}$ Concepts of standing to sue, ripeness for adjudication, mootness of controversy, and the "political question" doctrine have been so reworked that almost any legal contention may now be brought before the courts. ${ }^{20}$ Indeed, procedural objections to appellate lawmaking now more often than not are merely indirect adverse determinations of the contentions presented. As a practical matter, therefore, it may presently be easier for a litigant to get a law reform proposal into court than to get one out of a legislative committee. This is probably most clearly so of a proposal on behalf of a weak and divided interest, such as that of the poor.

From a substantive point of view, there appear to be a wide range of opportunities for judicial lawmaking with reference to the problems

14 See, e.g., Johnson v. New Jersey, 384 U.S. 719 (1966) (Miranda rules governing incustody interrogation to be applied only to cases in which the trial began after the date of the Miranda decision); United States v. Carolene Products Co., 304 U.S. 144, 152 n.4 (1938) (footnote indicating that closer scrutiny might be given to legislation restricting personal and political rights than to other legislation). Compare Baker v. Carr, 369 U.S. 186 (1962) (legislative apportionment held subject to judicial review) with Reynolds v. Sims, 377 U.S. 533 (1964) (legislature must be apportioned substantially on "one man, one vote" basis).

15 Compare Jones v. Mayer, 392 U.S. 409 (1968) (Civil Rights Act of 1866 bars private discrimination on the basis of race in the sale or rental of housing) with Bell v. Maryland, 378 U.S. 226 (1964) (civil rights "sit-in" conviction reversed and remanded to state court for further consideration where state criminal trespass statute was repealed subsequent to conviction).

10 See, e.g., Fen. R. Crv. P. 24; Cascade Natural Gas Corp. v. El Paso Natural Gas Co., 386 U.S. 129 (1967).

17 In Gideon v. Wainwright, 372 U.S. 335 (1963), amici curiae argued the case on both sides, and an amicus curiae brief was filed by twenty-two state governments. In Jones v. Mayer, 392 U.S. 409 (1968), twelve amicus curiae briefs were filed urging reversal and two urging affirmance.

18 See, e.g., Brown v. Board of Education, 345 U.S. 972 (1953), 374 U.S. 483 (1954), 349 U.S. 294 (1955).

19 See, e.g., White Motor Co. v. United States, 372 U.S. 253 (1963).

20 See A. Bickei, The least Dangerous Branch (1962); D. Currie, Federal Courts 6-20, $35-87$ (1968); Jaffe, Standing to Secure Judicial Review: Public Actions, 74 Harv. L. REv. 1265 (1961); Jaffe, Standing to Secure Judicial Review: Private Actions, 75 HARv. L. REv. 255 (1961); Scharpf, Judicial Review and the Political Question: A Functional Analysis, 75 YALE L.J. 517 (1966). 
of poverty. With important qualifications to be considered presently, reasonable chances of success have existed for inducing the courts to rework a formidable variety of legal rules concerning the poor. These opportunities include:

(1) Elimination of the residency requirement in eligibility for public insurance benefits; 21

(2) Equalization of state aid to public educational systems; ${ }^{22}$

(3) Invalidation of restrictions in the political or social freedom of public housing tenants; ${ }^{23}$

(4) Recognition of a tenant's right to withold paying rent on premises not in compliance with building codes; ${ }^{24}$

(5) Recognition of "overreaching" as a ground for invalidating a contract; ${ }^{25}$

(6) Elimination of wealth-related impediments to the right to be heard in adjudicative forums ${ }^{26}$ and to participate in the electoral process. ${ }^{27}$

In more general perspective, whereas the problem of poverty is essentially that of unequal income distribution, one of the least formally restricted guarantees in the Constitution is the equal protection clause. Surely the advocate can be found who would be willing to argue that equal protection is denied under a system of taxation and wealth transfer that fails to result in substantial equality of income. Most all other proposals to reform the law for the benefit of the poor would follow a fortiori.

From the perspective of legal services for the poor, the judicial way

21 See Shapiro v. Thompson, 394 U.S. 618 (1969) (state laws conditioning welfare assistance on one-year state residence held unconstitutional).

22 See McInnis v. Shapiro, 293 F. Supp. 327 (N.D. Ill. 1968), aff'd sub. nom., McInnis v. Ogilvie, 394 U.S. 322 (1969) (rejecting claim that equal protection clause requires apportionment of public school funds solely according to the educational needs of students).

23 See Thomas v. Housing Authority, 282 F. Supp. 575 (E.D. Ark. 1967) (local public housing authority may not automatically exclude or evict a low-income family on the sole ground that the head of the family or some other member has an illegitimate child).

24 See Brown v. Southall Realty Co., 237 A.2d 834 (D.C. Ct. App. 1968) (lease void where landlord at time of renting knew of housing code violations rendering premises unclean, unsafe, and unsanitary).

25 See Uniform Commercial Code § 2-302; Central Budget Corp. v. Sanchez, 53 Misc. 2d 620, 279 N.Y.S.2d 391 (Civ. Ct. N.Y. Cty. 1967) (excessively high price may constitute unconscionable contractual provision subject to invalidation).

26 Sniadach v. Family Finance Corp., 395 U.S. 337 (1969); Douglas v. California, 372 U.S. 353 (1963); Gideon v. Wainwright, 372 U.S. 335 (1963); Griffin v. Illinois, 351 U.S. 12 (1956); Sanks v. Georgia, 225 Ga. 88, 166 S.E.2d 19, prob. juris. noted, 395 U.S. 974 (1969).

27 Kramer v. Union Free School Diștrict No. 15, 395 U.S. 621 (1969); Harper v. Virginia Bd. of Elections, 383 U.S. 663 (1966). 
to law reform has at least three attractions compared with legislation. The first is that the courts are open as of right and must at least give ear to a presentation. The courts of first instance must hear any grievance that can be cast in the form of a legal action, and there are few that cannot. The right of appeal is substantially untramelled through the first appellate tier, and is reasonably open beyond that in most state court systems. Hearing before the Supreme Court of the United States is more difficult to obtain, but even there the matter is almost as nearly a matter of priority as one of privilege. In contrast, the legislature-whether federal, state, or municipal-can be a procedural labyrinth. Moreover, in the important matter of appearances, when a court rejects a proposal, it ordinarily is expected to give reasons. To those petitioning for the have-nots, that at least is consolation.

A second attraction of the judicial forum in anti-poverty law reform is its receptivity to argument based on principle. A judicial forum is expected to express rules of general application (in this sense, neutral ones), normative propositions that hold for all cases to which their terms apply. ${ }^{28}$ Specifically, the rules announced by courts are not supposed to be shaped by considerations of expediency, i.e., cost; a court is supposed to forswear any social or political program of its own, ${ }^{29}$ confining itself to issues on which there may be division of opinion but the resolution of which can be rested on some basis other than interest group lines as such. A forum in which discourse is conducted in arguments over principle is inevitably predisposed to claims in behalf of the poor, for all propositions for alleviating poverty involve essentially a competition between an ideal of equity and the problem of cost.

The third attraction of the judicial forum is the relatively insulated position from which it permits the advocate of legal change to operate. The advocate in the judicial "test case" has substantially all the privileges of the advocate in the mine-run legal controversy. The advocate's privilege presupposes that an outcome either way is a matter of no disturbing significance to the social system. It is one of full voice and no responsibility for consequences which may ensue if his argument is heeded. Although the very aim of a test case is to produce significant consequences through change in the law, the advocate in such a case nevertheless retains this privilege. He is regarded as a barrister rather than a lobbyist, his presentation is judged by its merit and not according

28 Bickel, Foreword: The Passive Virtues, 75 HARv. L. REv. 40 (1961); Wechsler, Toward Neutral Principles of Constitutional Law, 73 HARv. L. REv. 1 (1959).

29 See Kurland, Foreword: "Equal in Origin and Equal in Title to the Legislative and Executive Branches of the Government," 78 HARv. L. REv. 143 (1964); cf. Cox, Foreword: Constitutional Adjudication and the Promotion of Human Rights, 80 HARv. L. REv. 91 (1966). 
to the interests it may further, and he is not held accountable if the measures in question prove unworkable or unpopular.

The contrast between the role of judicial advocate for the poor and a legislative one could hardly be stronger: The former is regarded as an officer of the court, the latter something in the way of a political busybody. It is likely, in any event, that advocates for the poor can longer hold sway, and have better chances of continuing the appropriations for their agencies, if they concentrate their law-reform effort in the courts. Putting the proposition less softly, law reform in behalf of the poor creates fewer immediate ethical and political problems for its professional partisans when it is pursued in the courts rather than when it is pursued in the legislature.

\section{Limitations on Judicial Lawmaking}

Despite its attractions, a strategy of judicial lawmaking has limitations that considerably reduce its reform utility. Some of these concern the efficiency of the judicial process itself, others the effectiveness of the legislation it can produce.

The most serious limitation on the procedure of judicial lawmaking is its ephemeral legitimacy. Along any given frontier of the law, the appellate courts can only temporarily pursue a deliberate policy of development. As the line of new doctrine extends beyond the implications of prior legal consensus, each advance has less support in general assent, acknowledgment, and approval. Since courts lack altogether the means of formal policy ratification provided by the ballot box, each step of a pioneering course of decision rests to an increasing degree on its intrinsic merit in the eyes of the public and on the expectation that it will not be legislatively reversed. A court may for some time continue to be "right" and to be immune from immediate attack. At some point, however, a court functioning as though it had political mandate comes to be evaluated in those terms, and a constitutional crisis is presented. The Warren Court's encounter is only the most recent.

The courts of course cannot avoid substantial involvement in politically controversial questions, nor in legal choices which are equivalent to legislation. Their lawmaking function remains politically more tolerable, however, if the grist of their business is various and the direction of their policy indistinct. As performance of the judicial function becomes directional the protection accorded disinterestedness erodes. A law-reform strategy which necessarily involves continual testing of the limits of this protection would seem to have special dangers in an era when the virtue of disinterestedness is in perhaps critically short supply. 
Among other consequences, this kind of limitation means that judicial lawmaking compared to other processes of policy development is episodic in form and unfinished in product. Even with use of the devices mentioned earlier, ${ }^{30}$ appellate courts are not well equipped for devising systematic legal generalization. The differences between the legislative and judicial processes are many and subtle, but the ones salient for present purposes are not difficult to identify:

A court must work with the problem substantially as presented by the parties in respect to facts, ascription of responsibility, and theory of causation; a legislature has autonomous capacity to formulate the problem in all these respects.

A court must dispose of the case before it and having done so loses authority to act further until another germane case presents itself; a legislature can disregard the instance which excited its initial attention and can establish its own agenda for consideration of the problem type.

A court must tender its result and rationale as an accomplished fact, receiving commentary after the event; a legislature can present its result and rationale in proposal form for consideration and modification before official adoption.

Courts can extend a political principle more readily than they can initiate one, fill gaps but not build structures. In the law relating to the poor, the courts can enlarge eligibility at the margin of benefit schemes created by the legislature, such as public education or general assistance, but they cannot create the schemes in the first place. The courts can enforce building codes but they cannot write them. They can impose liability for fraud but cannot transform a vendor into a public utility. The difference is not one of will or effort but of institutional technique. Holmes summed up these propositions by saying that, in the main, courts operate in molecular dimensions rather than molar ones. ${ }^{31}$

Legislatures also have instruments that courts lack entirely. One is the authority to raise money. A court does not have a Ways and Means Committee. The inability to command money resources puts severe and insuperable limits on the potential scope of judicial law reform in behalf of the poor, whose central problems, after all, concern money. A closely related resource is the authority to create, empower, and deploy bureaucracies to get jobs done. Some of the problems of the poor can be solved by legal changes that are self-executing, but these are exceptional. The most important tasks require manpower: education requires teachers, jobs require recruiters and trainers, housing requires builders.

31 See Southern Pac. Co. v. Jensen, 244 U.S. 205, 221 (1917) (Holmes, J. dissenting); cf. Breitel, The Courts and Lawmaking, in LEgAL INSTITUTIONS TODAY AND TOMORROW (M. Paulsen ed. 1959). 
Another means which the legislature possesses but the judiciary lacks is that of stimulating and sustaining political support for measures that cost money or involve social dislocation. Legislators can hold hearings, make speeches, disseminate handouts, and speak to the Kiwanis. Judges, on the other hand, can speak ex cathedra only through written opinions; their unofficial addresses by tradition are confined to subjects other than those before their courts, and are ordinarily given before a bar association or at commencement exercises. No press conferences, no committee hearings, no stump speeches, no Face the Nation.

Without the instruments of modern political communication, community support cannot be cultivated for policy and program, and for it expression in law. No domestic policies and programs require more pervasive cultivation of support than those designed to benefit the have-nots, especially because so many of the have-nots are black. The procedure of judicial lawmaking includes no arrangements for assuring that its product has the direct sanction of general consent. Without such support, the Rule of Law in the short run assumes an autocratic connotation and in the long run invites subversion.

\section{Diremmas of a Legislative Strategy}

In the light of the limitations on what courts can do in law reform, the legislative course would seem obviously preferable for achieving law reform on behalf of the poor that is structural rather than symptomological, general in its effect rather than "show case." Economy in resource allocation within the law-reform effort would point to the same conclusion. Put bluntly, a law-reform strategy based on judicial action appears destined to yield relatively inconsequential results at relatively high political cost. The fairness of "kick out" procedure in inner city schools seems inconsequential compared with the "drop out" problem;32 the fairness of welfare eligibility rules seems inconsequential compared with the problem of welfare livelihood;33 the problem of housing codes is nothing to that of the housing shortage; ${ }^{34}$ and so on. It

32 Compare Howard v. Clark, 59 Misc.2d 327, 299 N.Y.S.2d 65 (N.Y. Sup. Ct. 1969) (New York Education Law does not permit suspension of public high school student for having been criminally charged with possession of narcotics) with NATIONAL COMMITIEE FOR CHILDREN AND Youth, Social DXNaMtTE: Report of the CONFERENGE ON UNEMPLOYED, OUT-OFSchool Youth IN URBAN AREAS 15 (1961) (Labor Department predicted that in 1960's more than $71 / 2$ million youngsters would drop out before high school graduation).

33 Compare Shapiro v. Thompson, 394 U.S. 618 (1969) (state laws conditioning welfare assistance on one-year state residence held unconstitutional) with R. ELMAN, THE POoRhouse State: The American Wax of Life on Public Assistance (1966).

34 Compare Brown v. Southall Realty Co., 237 A.2d 834 (D.C. Ct. App. 1968) (lease void where landlord at time of renting knew of housing code violations rendering premises unclean, unsafe and unsanitary) with N.Y. Times, March 16, 1969, at 1 (economists see it 
is not that these smaller problems should be ignored, or that a Legal Services Program should not seek their solution. The point is that they are relatively unimportant when the legal structure affecting the poor is viewed as a whole.

Why, then, the inattention to legislative law reform in the Legal Services Program? There seem to be two principal reasons: The style and self-image created in the Legal Services Program is discordant with an approach to social change that tends to succeed in the legislative process; and, a legislative reform strategy raises questions of politics and political ethics for the Legal Services Program that can be temporarily effaced or postponed in a judicial law-reform strategy.

The Legal Services Program's self concept is one of aggressive advocacy. The aggressiveness is expressed in the rhetoric of the program, in the continuous efforts to differentiate the new Legal Services from the old legal aid, in the recruitment of young, activist professional staffs, and in the program's strategic concept of the importance of institutional change in the alleviation of poverty. The role of advocate is expressed in the idea that the program has a client-the poor as a class-to which is owed the duty of single-minded loyalty and service as defined in the lawyer-client relationship. The function of the program is to speakpropose, exhort, argue-on behalf of a particular social constituency, imprecisely defined but sharply conceived as the economically destitute.

This style is appropriate in the representation of individual clients and, in qualified form, perhaps also in law reform through judicial lawmaking. It is quite inappropriate, generally speaking, in the legislative process.

Legislation is coalition work. Large majorities rather than bare majorities are required; appeal must be made to disparate interests on considerations less often of general principle than of parochial predisposition and prejudice; reciprocity is required through log-rolling or in the less obtrusive form of compensatory accommodations. Success in legislative advocacy requires long memory and personal sensitivity as much as intellectual acuity and rhetorical power. It requires endless patience, indirection in purpose, and protean adaptability. It requires finding of common interest among groups that have previously failed to recognize their common interest, rather than dramatic articulation of particularist minority claims. It requires acknowledgment of the present legitimacy of the status quo rather than attacks on its integrity. It is simply not a job for latter-day Darrows; an act of fantasy is required to see the idealized Legal Service Program lawyer-young, principled,

as virtually impossible to meet the Housing Act goal of 26 million new or rehabilitated housing units in the next decade). 
intrepid, and in a hurry-teasing a complicated statutory package through the legislative convolution.

The root of the style problem may well be simple. It is perhaps practically impossible over time to have a litigation-oriented legal services agency and a legislative law-reform agency under one roof. A litigation-oriented agency has to have direct client contact. These days the maintaining of client credibility, in the current phrase, requires presentation of the agency as assertive, uncompromising, and quickacting. For it to seek accomodation with divergent or hostile interests is to run the risk of being perceived as selling out; fabian tactics run the risk of being considered as indifference, long range solutions as delay. But surely it is possible to conceive of separate operating units for legislative law reform-units staffed and operated with an eye to the legislative process's time dimension, forms of discourse, and mode of decision.

It is not clear why the administration of the Legal Services Program has not invested more heavily than it has in creating and sustaining legislatively-oriented law reform units. It is now five years after the creation of the Program. A like number of years have passed since recognition of the saliency in the poverty problem of education, markets, jobs, and housing. Yet technically precise and programmatically coherent drafts of statutes on most facets of these subjects remain to be written..$^{35}$ The explanation may be persisting faith in the comparative efficacy of judicial law reform, lack of an appealing model (as the private law office is the model for litigation-oriented legal service), or simple inattention. It may also be attributable to more or less unconscious recognition of the political implications of making law reform an objective of the Legal Services Program.

A law-reform strategy has political implications of two different magnitudes. Both are involved whether the law-reform technique is judicial or legislative, but they are more obvious in a legislative strategy. One implication concerns choices to be made within a legal assistance program as to who shall receive the services of the program. This is essentially a question of how to deploy the agency's resources. The other question is whether any governmentally funded agency can long enjoy support if its program consists of lobbying for an interest group. In practical terms, this is essentially a question of agency survival.

At any given magnitude of legal services resources, to pursue law reform is to forego providing other legal services of equivalent cost.

35 See, e.g., American Bar Foundation, Model Residentual Landlord-Tenant Code (Tent. Draft, 1969); National. Conference of Commissioners on Uniform State Laws, Uniform Consumer Credit Code (Final Draft, 1968). 
Since the demand for front-line legal assistance has proved highly elastic at present service levels, diversion of resources to law reform involves making a choice between two groups of potential beneficiaries of legal service, those who require "first aid" and those who would ultimately benefit from law reform, judicial or legislative. The choice is a political one in the sense that it is based on a calculation of relative social expediency of one expenditure of effort compared to another.

Making such a choice between clients is not contemplated in the ethics and conventions defining the lawyer's role, certainly not in those defining the advocate's role. According to the canons and traditions, the lawyer's selection of clients is governed only by such considerations as who has first sought the lawyer, who is willing to pay more, and whose cause the lawyer finds more professionally interesting. None of these are illuminating or even relevant to the problem of allocating legal service resources as between legal "first aid" and law reform. The same kind of problem arises concerning the direction in which law reform efforts should be aimed. There is no unanimity as to which laws most need changing, nor as to the kinds of change they ought to undergo. In providing legal service to paying clients, the lawyer does not make this decision; the client does so, according to his estimateinformed by the lawyer - as to the cost and prospective benefit of doing so. In a publicly funded legal assistance program, however, the legal service agency decides the question by deciding which causes to promote.

In this perspective, there is no difference in principle or political reality between adjudicative and legislative law reform. There is a difference, to be sure, in visibility and responsibility. A law office conducting test-case litigation is not ostensibly a federal agency constituted to reform local law and government. Yet the disguise is not very convincing, and never was to such political realists as Mayor Daley of Chicago and Governor Reagan of California. ${ }^{36}$ The question in testcase litigation, as in legislative law reform, boils down to the propriety of constituting a publicly funded agency to lobby for the special benefit of a limited sector of the general community.

Such instrumentalities are not unprecedented. Many governmental

36 There was a protracted and barely muffled controversy as to whether the Chicago legal service agencies funded by the OEO should be authorized to sue agencies of state and city government. The Legal Services Program insisted that such authority should not be withheld. The formal resolution of the controversy was never very clear, though in the course of events legal aid litigation against state and city agencies in Chicago has proved rare. The controversy in California concerned gubernatorial approval of refunding of the California Rural Legal Agency Assistance, Inc. See N.Y. Times, Sept. 24, 1967, at 61; cf. Note, Neighborhood Law Offices, 80 HARv, L. REv. 805 (1967). 
agencies are in some degree legislative advocates for the private interests with which they are associated. Tax deduction of business's costs of legislative advocacy has long acquiescence if not approval. ${ }^{37}$ Consumer counsel agencies at the state and federal level have constituencies that are not really universal..$^{38}$ And states have given preferential subsidy to political parties by means of legislation requiring hourly workers to be compensated for time to go to the polls. ${ }^{39}$ There is nevertheless a serious if simple question of principle involved, namely, whether government predicated on equal participation of all members of the electorate is compatible with providing some of them with special political equipage at public expense.

The instances cited above in which some such equipage has been provided were not results of considered design. The friendly posture of some government agencies to their private subjects of regulation is a failing of political purpose, lamentable and correctable even while being a persistent tendency. The theory at any rate of business tax deduction of legislative advocacy costs is derived from the idea that a business's legal expenses, like its other operating expenses, are deductible. Similarly, the suppositions are that everyone has a consumer's interest and that reimbursement of voting time for hourly wage employees simply puts them on equal footing with salaried workers and proprietors. Realism requires recognition that these justifications are not entirely convincing, that they are not clearly fulfilled in practice, and that there is ambivalence in objecting on principle to creating a government lobby for the poor when everyone else already seems to have one.

The fact remains that in a constitutional regime partisan political activity is supposed to be a matter of private initiative. For such a regime to survive it has to stay pretty much that way in fact. However inconstantly the principle is fulfilled, it rests on a recognition that a government which creates agencies to formulate what shall be taken as the people's will is no longer a government by the people. The force of the point is suggested by asking what would be the consequences of generalizing the proposition that the poor should have lobbyists paid by the government: Should similar lobbyists be provided the near-poor, the middle-class, the affluent? How does one rationally allocate the

37 Cooper, The Tax Treatment of Business Grassroots Lobbying, Defining and Attaining the Public Policy Objectives, 68 Colum. L. Rev. 801 (1968); Weaver, Taxes and Lobbying-The Issue Resolved, 31 GEO. WASH. L. REv. 938 (1963).

38 Note, Consumer Legislation and the Poor, 76 YALE L.J. 745 (1967); Comment, Translating Sympathy for Deceived Consumers Into Effective Programs for Protection, 114 U. PA. L. REv. 395 (1966).

39 Day-Brite Lighting v. Missouri, 342 U.S. 421 (1952), noted in 1952 U. ILL. L.F. 442. 
political resources through which resource allocation is made? One comes uneasily to the conclusion that the idea simply does not have sustaining attraction.

The conclusion also suggests itself that the idea of "Iobbyists for the poor" is both precious and irrelevant. It seems to be an attempt to create a role for middle-class professionals in which they can aid the cause of the poor without losing their professional status or otherwise getting their hands dirty. It seems irrelevant because it places legal action and political action in the wrong sequence. Legal steps toward law reform are taken when political imperatives are strong enough to require them. Political imperatives are the result of political organization and political pressure.

If the interest groups that comprise the poor do not organize their own political action, law reform on their behalf is almost certainly destined to be halting and fragmentary. If they do organize their own political action, it is hard to see why they will select self-constituted lobbyists for the poor as their advocates. More probably, as everyone else does, they will choose advocates when the time comes and according to who can do the best job, not who most wants to do the job. Probably, too, the selection will be of rough and ready bargainers rather than academically groomed professional technicians.

What the interest groups among the poor will need from the professional technicians are specific reform proposals that can be sold. Reform proposals meeting the test of the political market place must be related to some general principle of fairness or justice, respond to interests broad enough to command the necessary votes, and represent a coherent piece of work from a technical point of view.

The task of drafting law-reform proposals that meet these tests is exacting, time-consuming, and expensive. Drafting such proposals is the vocation of agencies whose endeavors have been regarded as standing on the legitimate side of the line between legal policy analysis and lobbying, for example, the National Conference of Commissioners on Uniform Laws, the American Law Institute, the Brookings Institution, the Legislative Drafting Service of Columbia Law School, the law revision commissions of several states, and an unending series of ad hoc commissions at every level of government. Just why this approach to law reform has not been seriously pursued through the Legal Services Program is not clear. 